\title{
LIÇÃO DE VIDA: 90 ANOS DA PROFESSORA ELOISA MANO
}

Para quem a conhece bem, é difícil encontrar palavras para descrever a Professora Eloisa Mano - brilhante, determinada, exigente, excelente e muito mais. Porém, conforme ela mesma costuma dizer, a palavra que melhor descreve sua trajetória de vida é: Pesquisadora. A curiosidade científica é uma constante em sua vida, bem como a persistência necessária para trabalhar com pesquisa. É movida por essas virtudes. Tornou-se referência nacional e internacional no campo da Ciência e Tecnologia de Polímeros. Com argúcia e perspicácia, sempre enxergou à frente do seu tempo. Em 1968, numa época em que ninguém sabia ao certo o que eram polímeros, ela idealizou e criou a semente do que viria a se tornar o Instituto de Macromoléculas Professora Eloisa Mano (IMA). Foi pioneira na reciclagem de plásticos pós-consumo no meio universitário, e estimulou a aproximação dos meios acadêmico e industrial no tocante a polímeros. Estabeleceu laços com os principais nomes da área em todo o mundo, abrindo portas para os profissionais e estudantes do IMA. Uma de suas citações favoritas pode ser ilustrativa pelo seu modo de encarar a vida e seus desafios: "Não chores, meu filho; não chores, que a vida é luta renhida: viver é lutar. A vida é combate, que os fracos abate, que os fortes, os bravos só pode exaltar." ( $1^{\mathrm{a}}$ estrofe da Canção do Tamoio, de Gonçalves Dias).

Falar da Professora Eloisa é falar do IMA. Como em tudo o que faz, deixou nele seu toque de mestre: projetou meticulosamente o ambiente que desejava, tratando dos detalhes da forma - o projeto do prédio do IMA. Ela concebeu o jardim interno do prédio para assemelhar-se a um pedaço de morro (em suas próprias palavras), e nele colocou um chafariz para criar um microclima agradável e atenuar a aridez dos prédios do Centro de Tecnologia da UFRJ. Diversas espécies de pássaros frequentam esse pequeno oásis, e ajudam a Professora a espairecer em dias mais difíceis, nos quais ela senta-se num banco perto de seu gabinete para contemplá-los. A exemplo da Professora, a atmosfera do IMA acolhe, recebe, apoia e estimula. Em cada canto do Instituto respira-se inteligência, ideias e conhecimento. É comum ex-alunos permanecerem no Instituto após concluir seus estudos, tornando-se pesquisadores, funcionários ou docentes. Mesmo aqueles que se colocam em outras ocupações, fazem questão de manter contato, estabelecer parcerias e participar dos eventos realizados no IMA.

Através de seu trabalho, exemplo e dedicação, Eloisa Mano motivou pessoas à sua volta, e construiu um centro de excelência que se tornou não apenas a sua "casa", mas também a "casa" de muitas outras pessoas apaixonadas por Ciência como ela. Os alunos são seus "filhos" adotivos, que ela orienta, ampara, aconselha e ajuda. A despeito de seus 90 anos, completados há pouco, nossa querida mestra frequenta regularmente o Instituto que fundou, onde além de escrever livros e disseminar ideias para novas pesquisas, reúne seus colegas e alunos mais chegados para o tradicional café com biscoitos - feito e servido por ela mesma em seu gabinete. Sempre com muita alegria e o mesmo entusiasmo.

Professor Luis Claudio Mendes

Diretor

Instituto de Macromoléculas Professora Eloisa Mano

Universidade Federal do Rio de Janeiro 